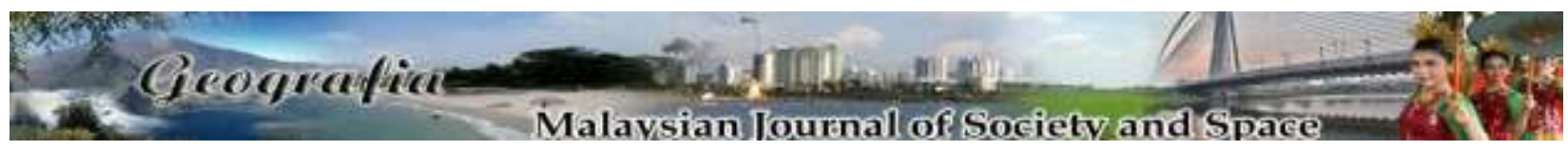

\title{
Pelaksanaan Amalan Pertanian Baik (GAP) dalam kalangan pesawah padi di Sekinchan, Sabak Bernam, Selangor
}

\author{
Nurul Izzati Mohd Ali ${ }^{1}$, Nur Illyani Ibrahim ${ }^{2}$, Kadaruddin Aiyub ${ }^{1}$, Saraswathy Kasavan ${ }^{3}$ \\ ${ }^{1}$ Pusat Kajian Pembangunan, Sosial dan Persekitaran, Fakulti Sains Sosial dan Kemanusian, Universiti \\ Kebangsaan Malaysia \\ ${ }^{2}$ Kementerian Air, Tanah dan Sumber Asli, Wisma Sumber Asli, Putrajaya, Malaysia \\ ${ }^{3}$ Institut Pembangunan dan Alam Sekitar, Universiti Kebangsaan Malaysia \\ Correspondence: Kadaruddin Aiyub (email: kada@ukm.edu.my)
}

Received: 16 September 2019; Accepted: 30 March 2020; Published: 28 August 2020

\begin{abstract}
Abstrak
Senario industri pertanian di seluruh dunia kini sedang beralih daripada pertanian konvensional kepada pertanian lestari. Amalan pertanian baik (GAP) telah diperkenalkan sebagai panduan dalam melaksanakan pertanian lestari yang mengambil kira kepentingan ekonomi, alam sekitar dan sosial dalam menghasilkan makanan yang berkualiti dan selamat dimakan. Kajian ini dijalankan di Sekinchan iaitu sebuah kawasan penanaman padi paling maju di negeri Selangor dengan keluasan keseluruhan 1857 hektar sawah padi. Kajian ini bertujuan untuk menilai pelaksanaan Malaysian Good Agriculture Practice (MyGAP) di antara pesawah yang mempunyai pensijilan MyGAP dan tidak mempunyai MyGAP. Pada peringkat pertama, amalan pertanian baik telah dikenalpasti daripada analisis dokumen berdasarkan standard GAP di Malaysia. Pada peringkat kedua, mengisi senarai semak berdasarkan data yang diperoleh daripada pemerhatian dan temu bual dengan empat orang pesawah yang mempunyai sijil MyGAP dan empat orang tidak mempunyai sijil MyGAP. Hasil kajian mendapati amalan pertanian yang dilaksanakan oleh pesawah di kawasan kajian adalah pada tahap yang sederhana di mana hanya tiga daripada empat komponen GAP yang dilaksanakan dan melibatkan sembilan daripada 13 elemen GAP sahaja. Sumbangan kajian ini dapat dijadikan input kepada pihak-pihak berkepentingan untuk tujuan penambahbaikan dalam tatacara pengurusan pensijilan MyGAP ke arah mesra alam sekitar disamping memastikan penghasilan makanan yang berkualiti, sihat dan selamat dimakan.
\end{abstract}

Kata kunci: elemen MyGAP, komponen MyGAP, MyGAP, pengurusan sawah, pertanian lestari, pertanian padi 
GEOGRAFIA Online ${ }^{\mathrm{TM}}$ Malaysian Journal of Society and Space 16 issue 3 (247-262)

(C) 2020, e-ISSN 2682-7727 https://doi.org/10.17576/geo-2020-1603-18

\title{
Implementation of Good Agricultural Practices (GAP) among paddy farmers in Sekinchan, Sabak Bernam, Selangor
}

\begin{abstract}
The scenario of the agricultural industry around the world is now shifting from conventional agriculture to sustainable agriculture. Good agricultural practice (GAP) has been introduced as a guide in implementing sustainable agriculture which takes into account the importance of economy, environment and society in producing quality food that is safe to eat. This study was conducted in Sekinchan, a high-yielding paddy cultivation area with the highest production per hectare in Malaysia. This study aims to evaluate MyGAP (Malaysian Good Agriculture Practice) implementation among farmers who have MyGAP certification and without MyGAP certification. In the first stage, GAP have been identified from document analysis based on the standard of GAP in Malaysia. In the second stage, fill out the checklist based on data obtained from observations and interviews with four farmers who have MyGAP certification and four farmers without MyGAP certification. The findings show that agricultural practices carried out by paddy farmers in the study area are at moderate level where only three out of four components of GAP were implemented which consist nine out of the 13 GAP elements. The contribution of this study can be used as input to stakeholders for the purpose of improving the existing MyGAP certification management procedures towards environmental friendly besides producing quality, healthy, and safe to eat food.
\end{abstract}

Keywords: elements of MyGAP, components of MyGAP, MyGAP, paddy field management, sustainable agriculture, paddy farming

\section{Pengenalan}

Sektor pertanian merupakan antara sektor industri yang turut menyumbang kepada pencemaran alam sekitar terutama ketika mengamalkan kaedah pertanian konvensional. Kaedah pertanian konvensional mampu memaksimumkan hasil pertanian dan keuntungan melalui penggunaan jentera, baja kimia sintetik, pestisid dan organisma terubah suai secara genetik (genetically modified organisms atau GMO) (Gomiero, 2018). Walau bagaimanapun, kaedah pertanian konvensional tersebut tidak mengambil kira kesan secara tidak langsung bagi jangka panjang terhadap dinamik ekologi pertanian dan biodiversiti (Tsutsui et al., 2018). Penggunaan bahan kimia berupaya memerangi rumpai dan makhluk perosak bagi menyuburkan tanaman dan meningkatkan produktiviti tanaman. Namun, kesan daripada penggunaan bahan kimia secara berleluasa boleh membahayakan alam sekitar, sistem ekologi dan juga kesihatan manusia. Pencemaran (air, udara, tanih), penebangan hutan dan perubahan iklim adalah juga sebahagian kesan negatif yang wujud daripada aktiviti pertanian secara konvensional. Menyedari hakikat ini, sistem pertanian di seluruh dunia telah mengalami evolusi daripada pertanian secara konvensional kepada pertanian lestari. Pertanian lestari atau pertanian agroekologi merupakan suatu sistem pertanian alternatif yang mampu untuk memenuhi keperluan makanan global secara lestari dan cekap (Mishra et al., 2018). Pada masa yang sama, kaedah pertanian lestari dapat memastikan penjagaan mesra alam sekitar serta meningkatkan produktiviti dan keuntungan 
GEOGRAFIA Online ${ }^{\mathrm{TM}}$ Malaysian Journal of Society and Space 16 issue 3 (247-262)

(C) 2020, e-ISSN 2682-7727 https://doi.org/10.17576/geo-2020-1603-18

kepada petani. Pertanian lestari kini menjadi agenda utama bagi institusi-institusi pertanian di seluruh dunia dan mampu menjadi penyelesaian kepada isu-isu berkaitan dengan pertanian konvensional. Ia telah membawa ke arah peningkatan pendapatan petani serta kualiti makanan (Feher \& Beke, 2013).

Selaras dengan menekankan pertanian lestari, Pertubuhan Makanan dan Pertanian Bangsa-Bangsa Bersatu (Food and Agriculture Organization of the United Nations - FAO) telah memperkenalkan amalan pertanian baik atau good agricultural practice (GAP) (FOA, 2003) GAP tersebut menekankan aspek tentang pemuliharaan dan pemeliharaan alam sekitar serta pengurangan pencemaran sebagai komponen penting. Sehingga kini, GAP semakin diterima oleh petani untuk melaksanakan dalam aktiviti pertanian mereka. Ia turut memberikan indikasi bahawa petani semakin sedar terhadap kepentingan penjagaan alam sekitar dalam melaksanakan aktiviti pertanian mereka. Skim persijilan Amalan Pertanian Baik Malaysia (Malaysian Good Agricultural Practice atau MyGAP) telah dilancarkan oleh Kementerian Pertanian dan Industri Asas Tani (MOA) pada 28 Ogos 2013 bagi menggalakkan pengeluaran produk pertanian Malaysia yang berkualiti dan selamat dimakan untuk kegunaan domestik dan pasaran eksport. Selain itu, daya saing produk pertanian Malaysia di peringkat antarabangsa juga dapat ditingkatkan melalui penanda aras dengan skim pensijilan GAP antarabangsa seperti ASEAN GAP dan GLOBALG.A.P (MOA, n.d.).

Padi adalah tanaman makanan ruji bagi penduduk di Malaysia serta merupakan komoditi yang terpenting dalam agenda jaminan bekalan makanan negara (Doni et al., 2016). Justeru itu, amalan pertanian yang berlaku di sepanjang rantaian pengeluaran padi perlu diubah mengikut amalan pertanian yang lestari seperti yang ditetapkan oleh MOA. MOA bersama-sama Lembaga Kemajuan Pertanian Muda (MADA) telah mengeluarkan dan mengedarkan Senarai Semakan Tanaman Padi (Rice Check) memberikan satu garis panduan amalan pertanian yang terperinci untuk menguruskan tanaman padi mengikut keperluan MyGAP kepada semua pesawah padi di seluruh negara (MADA 2015). Namun, pengaplikasi setiap komponen dan elemen GAP untuk aktiviti pertanian padi dalam kalangan pesawah masih lagi dipersoalkan.

Mengikut IADA Barat Laut Selangor, (n.d.) dan Jabatan Standard Malaysia, (2016), jumlah kawasan pertanian padi yang telah mendapat persijilan dengan MyGAP masih rendah sedangkan skim persijilan ladang ini bukanlah suatu skim yang baharu. Sebaliknya, konsep MyGAP merupakan penjenamaan semula daripada skim-skim persijilan yang sebelum ini seperti Skim Amalan Ladang Baik Malaysia (SALM), Skim Akreditasi Ladang Ternakan (SALT) dan Skim Pensijilan Ladang Akuakultur Malaysia (SPLAM). Dalam Rancangan Malaysia Ke-11 (2015-2020), dilaporkan bahawa sehingga tahun 2014, hanya 4.6\% sahaja (3585 ladang pertanian daripada keseluruhan 77191 ladang pertanian) di seluruh Malaysia yang telah mematuhi MyGAP (EPU, 2015). Daripada jumlah ini, hanya 38\% merupakan ladang tanaman makanan yang meliputi sawah padi, ladang sayur-sayuran dan ladang buah-buahan. Oleh itu, kajian ini bertujuan untuk mengisi jurang kajian dengan menilai pelaksanaan MyGAP di antara pesawah yang mempunyai pensijilan MyGAP dan tidak mempunyai MyGAP di Sekinchan.

\section{Peranan MyGAP di Malaysia}

Pengertian istilah amalan pertanian baik (GAP) adalah pelbagai konteks mengikut standard dan keperluan petani yang berbeza (FOA, 2003). Definisi konsep bagi GAP boleh ditakrifkan sebagai suatu set amalan, keadaan sistem, atau protokol yang berkaitan dengan pengurusan aktiviti pertanian di peringkat ladang dan pasca pengeluaran bagi menghasilkan barangan buatan dan 
GEOGRAFIA Online ${ }^{\mathrm{TM}}$ Malaysian Journal of Society and Space 16 issue 3 (247-262)

(C) 2020, e-ISSN 2682-7727 https://doi.org/10.17576/geo-2020-1603-18

produk makanan yang selamat serta berkualiti dengan mengambil kira aspek kemampanan ekonomi, sosial dan alam sekitar (Srisopaporn et al., 2015). Selain itu, GAP menjadi rujukan dalam rangka kerja kawal selia antarabangsa di mana telah diaplikasi oleh kebanyakan kerajaan dan juga badan bukan kerajaan (FOA, 2003).

Pertambahan penduduk di Malaysia bagi setiap tahun telah menyebabkan permintaan tinggi terhadap sumber bekalan makanan terutama beras. Oleh itu, aktiviti pertanian giat telah dijalankan untuk menghasilkan produktiviti yang tinggi tanpa mengutamakan aspek mesra alam sekitar. Sehubungan itu, penubuhan GAP telah wujud sekitar akhir abad ke-20an sebagai garis panduan dalam sektor pertanian untuk memaksimumkan produktiviti pertanian di samping menerapkan aspek mesra alam sekitar. Senario ini membawa kepada pembentukan Agenda 21 semasa Persidangan Alam Sekitar dan Pembangunan Pertubuhan Bangsa-Bangsa Bersatu (United Nations Conference on Environment and Development - UNCED) yang diadakan di Rio de Janeiro, Brazil pada tahun 1992 (Chan, 2016). Artikel 14 dalam Agenda 21 ada juga menyentuh mengenai pembangunan pertanian dan luar bandar yang lestari (sustainable agriculture and rural development - SARD). Keutamaan artikel tersebut bertujuan untuk mengekalkan dan meningkatkan keupayaan tanah pertanian bagi memenuhi permintaan makanan penduduk di samping memulihara dan memelihara sumber semula jadi bagi mengekalkan nisbah manusia/tanah (UNCED, 1992).

Di Malaysia, Skim Amalan Pertanian Baik Malaysia atau lebih dikenali sebagai MyGAP merupakan pensijilan yang komprehensif untuk sektor pertanian bagi mengiktirafkan ladang yang mengamalkan amalan pertanian baik. MyGAP merupakan pematuhan kepada piawaian Malaysian Standard (MS) iaitu MS 1784:2016 Good Agricultural Practice (GAP) - Crop Commodities (Second Revision) digunakan bagi modul sektor tanaman (MOA, 2013). Pelaksanaan standard ini dapat menghasilkan produk pertanian yang selamat dan sihat untuk dimakan kerana bebas daripada risiko racun serta membantu membangunkan industri pertanian negara yang lebih mesra alam sekitar.

\section{Lokasi Kajian}

Sekinchan merupakan sebuah pekan kecil yang terletak dalam Mukim Pasir Panjang di Daerah Sabak Bernam, Selangor di antara latitud $3^{\circ} 30^{\prime} 22^{\prime \prime} \mathrm{U}$ dan longitud $101^{\circ} 06^{\prime} 21^{\prime \prime} \mathrm{T}$ dengan keluasan 8548.77 hektar. Majoriti penduduknya adalah kaum Cina (60\%) diikuti oleh kaum Melayu (30\%) dan kaum-kaum lain (10\%) (Mohd Hafizi, 2014). Mengikut sejarah, masyarakat Cina di Sekinchan berasal dari Pahang dan Kedah yang berhijrah ke Sekinchan untuk menanam padi dan mencari penempatan baharu (Ili Akmal Mohd Razif, 2015). Aktiviti ekonomi utama di Sekinchan adalah pertanian di mana sebanyak $76.52 \%$ atau 6541.52 hektar keluasan tanah telah digunakan sebagai kawasan pertanian. Sekinchan merupakan jelapang padi kedua terbesar di Malaysia selepas Negeri Kedah. Sekinchan juga terkenal dengan pengeluaran padi per hektar yang tertinggi di Malaysia iaitu melebihi 10 tan metrik per hektar per musim. Aktiviti penanaman padi di kawasan ini dijalankan sebanyak dua kali setahun. Pada musim utama penanaman padi bermula pada bulan September dan berakhir pada bulan Disember. Manakala penanaman di luar musim pula dijalankan bermula bulan Mac dan berakhir pada bulan Jun tahun berikutnya. Jadual 1 menjelaskan aktiviti penanaman padi di Sekinchan sepanjang tahun. Mengikut DOA (2016), keluasan sawah padi di Sekinchan yang telah dipersijilkan dengan MyGAP adalah sebanyak 31.2 hektar (1.68\%) daripada keluasan keseluruhan 1857 hektar sawah 
padi. Terdapat 26 pesawah (7.20\%) yang terlibat dalam pensijilan MyGAP daripada keseluruhan 361 pesawah.

Jadual 1. Aktiviti penanaman padi di Sekinchan

\begin{tabular}{lll}
\hline $\begin{array}{l}\text { Musim Penanaman } \\
\text { Padi }\end{array}$ & Waktu (Bulan) & Aktiviti \\
\hline Musim Utama & Awal September & Penanaman padi \\
& Pertengahan September-pertengahan November & Pertumbuhan padi \\
& Pertengahan November & Padi matang \\
& Disember & Penuaian padi \\
& Januari - Februari & Pembersihan sawah dan rehat \\
\hline Luar Musim & Awal Mac & Penanaman padi \\
& Pertengahan Mac - pertengahan Mei & Pertumbuhan padi \\
& Pertengahan Mei & Padi matang \\
& Jun & Penuaian padi \\
& Julai - Ogos & Pembersihan sawah dan rehat \\
\hline
\end{tabular}

Sumber: DOA (2016)

\section{Metod Kajian}

Terdapat pelbagai fenomena yang tidak dapat diterangkan secara jelas dengan hanya menggunakan kaedah kuantitatif. Terdapat beberapa kes khas yang memerlukan pemerhatian, temu bual dan dokumen analisis untuk mendapat data yang tepat dan bernilai. Oleh itu, kajian ini mengunakan kaedah kualitatif supaya dapat memberi maklumat terperinci bagi membuat interpretasi yang jelas dan menjawab objektif kajian. Kajian ini dijalankan dalam dua peringkat seperti yang ditunjukkan pada Rajah 1. Pada peringkat pertama komponen dan elemen MyGap telah dikenal pasti daripada dokumen analisis yang berkaitan MyGap dalam konteks pertanian padi di Malaysia. Komponen dan elemen MyGap tersebut dipaparkan dalam bentuk jadual sebagai senarai semak. Senarai semak tersebut dibahagi kepada 3 kategori iaitu: (1) tidak dilaksanakan; (2) dilaksanakan; dan (3) dilaksanakan dengan teratur dan sistematik. Di peringkat kedua, penyelidik mengisi senarai semak tersebut berdasarkan data yang diperoleh daripada temu bual separa berstruktur dan pemerhatian. Penyelidik memerhatikan tingkah laku informan (pesawah) semasa menjalankan aktiviti pertanian di kawasan kajian. Setiap tingkah laku informan akan dicatatkan dalam borang nota pemerhatian dan dijadikan sebagai data untuk memerhati amalan pertanian yang dijalankan oleh mereka. Kajian ini turut menggunakan pendekatan temu bual separa berstruktur dengan berpandukan satu skrip umum (set protokol) yang merangkumi soalan-soalan berkaitan dengan komponen dan elemen MyGAP. 


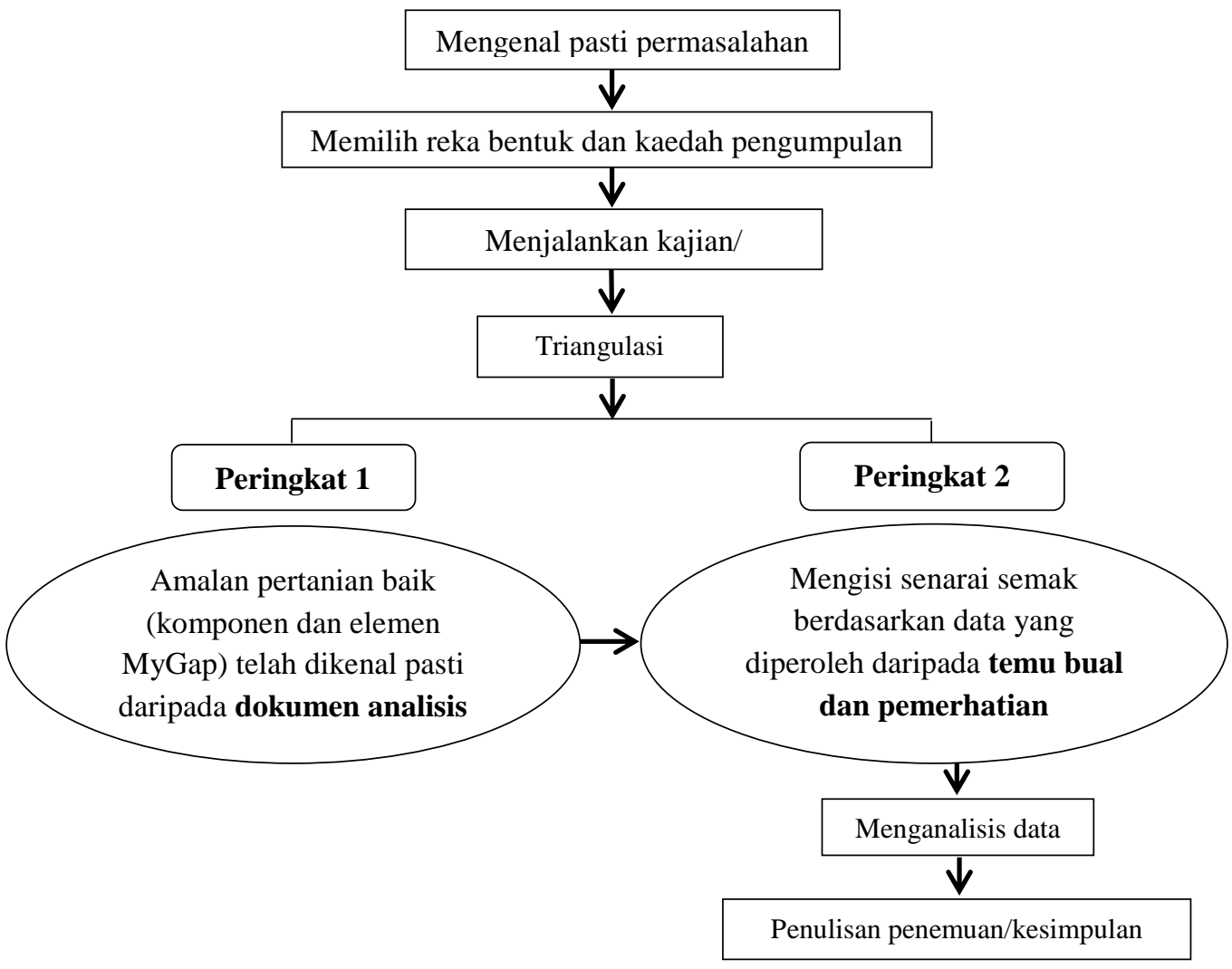

Rajah 1. Tatacara analisis kajian

Kaedah persampelan bertujuan (purposive sampling) telah digunakan bagi pemilihan informan kajian seperti yang ditunjukkan pada Rajah 2. Proses pemilihan dimulakan dengan menetapkan beberapa ciri-ciri yang diperlukan berdasarkan objektif kajian. Pertama, individu yang dipilih sebagai informan kajian dalam kalangan pesawah padi yang mempunyai pensijilan MyGAP dan tidak mempunyai pensijilan MyGAP. Kedua, pengeluaran padi yang dihasilkan oleh informan adalah sekurang-kurangnya pada tahap sederhana iaitu enam tan metrik per hektar per musim. Penetapan kedua-dua kriteria ini bertujuan untuk memastikan data yang dikutip secara menyeluruh dan mendalam. Seterusnya, penyelidik telah mendapatkan kerjasama daripada pihak Jabatan Pertanian Negeri Selangor dan Pejabat Pertanian Daerah Sabak Bernam untuk membuat pencalonan informan. Hal ini kerana maklumat mengenai hasil pengeluaran padi dan senarai calon yang mempunyai pensijilan MyGAP hanya dimiliki oleh jabatan ini. Penetapan jumlah informan seramai lapan orang sudah mencukupi dalam kajian ini untuk mendapatkan data pada kadar yang tepu (saturation level) (Cooper, \& Schindler, 2001). 


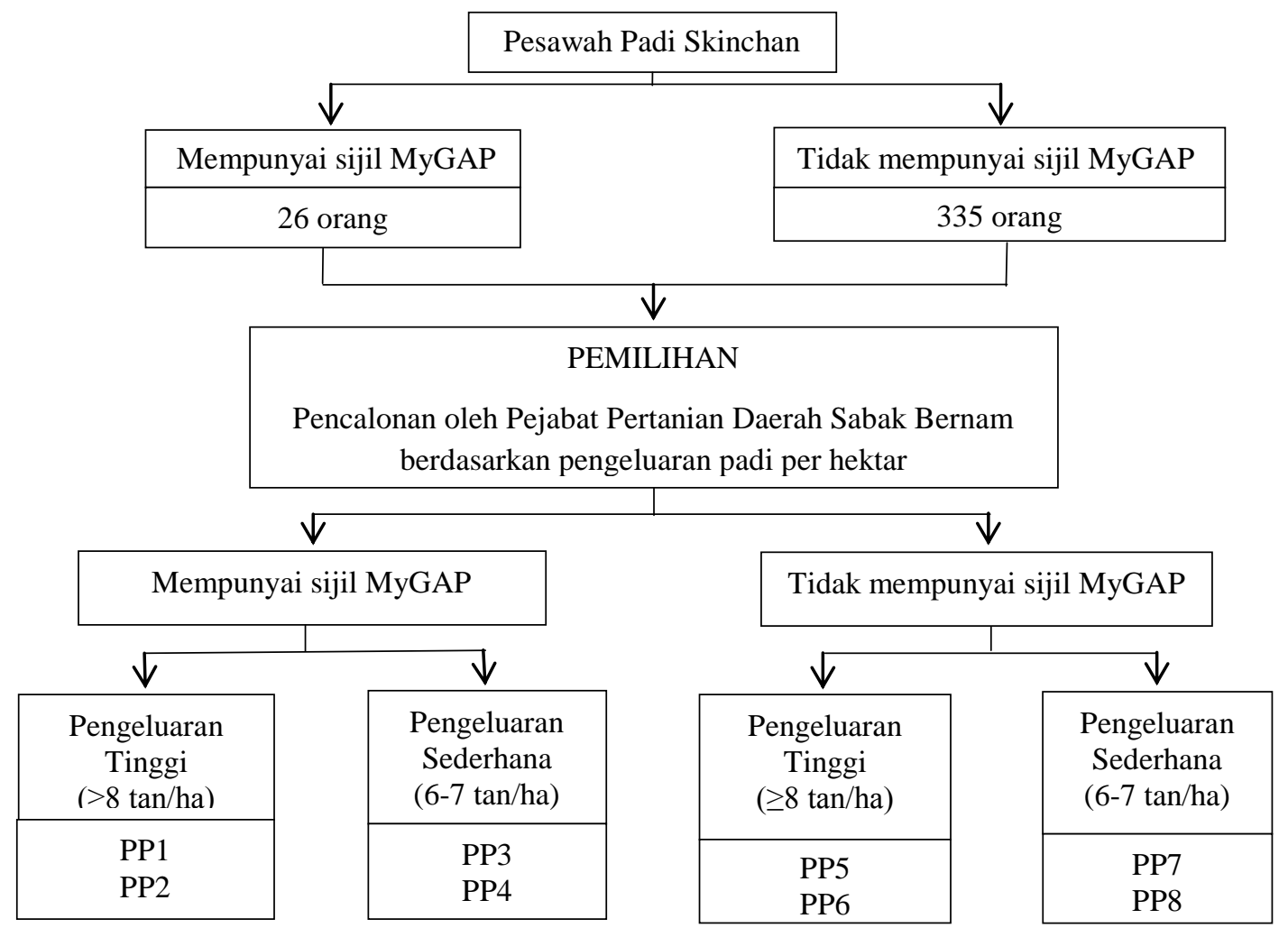

Rajah 2. Proses pemilihan informan kajian

\section{Penemuan dan Perbincangan}

Informan PP1 hingga PP4 merupakan pesawah padi yang telah mempunyai pensijilan MyGAP untuk sawah padi mereka manakala informan PP5 hingga PP8 merupakan pesawah padi yang tidak mempunyai pensijilan MyGAP. Profil lengkap mengenai semua informan pesawah padi ditunjukkan seperti dalam Jadual 2.

Jadual 2. Profil pesawah padi

\begin{tabular}{|c|c|c|c|c|c|c|c|c|}
\hline \multirow{2}{*}{$\begin{array}{l}\text { Profil Informan } \\
\text { Kajian }\end{array}$} & \multicolumn{4}{|c|}{ Pesawah Mempunyai Pensijilan MyGAP } & \multicolumn{4}{|c|}{$\begin{array}{l}\text { Pesawah Tidak Mempunyai } \\
\text { Pensijilan MyGAP }\end{array}$} \\
\hline & PP1 & PP2 & PP3 & PP4 & PP5 & PP6 & PP7 & PP8 \\
\hline Umur (tahun) & 62 & 71 & 52 & 40 & 59 & 28 & 38 & 27 \\
\hline Keturunan & Cina & Cina & Cina & Cina & Cina & Cina & Cina & Cina \\
\hline Jantina & Lelaki & Lelaki & Lelaki & Perempuan & Lelaki & Lelaki & Lelaki & Lelaki \\
\hline $\begin{array}{l}\text { Tahun mendapat } \\
\text { pensijilan MyGAP }\end{array}$ & 2017 & 2016 & 2016 & 2017 & - & - & - & - \\
\hline $\begin{array}{l}\text { Keluasan sawah yang } \\
\text { diusahakan (ha) }\end{array}$ & 1.2 & 1.2 & 1.2 & 1.2 & 1.2 & 1.2 & 1.2 & 1.2 \\
\hline Status pemilikan sawah & Sendiri & Sewa & Sewa & Sendiri & Sendiri & Sendiri & Sewa & Sendiri \\
\hline $\begin{array}{l}\text { Pengalaman } \\
\text { mengusahakan sawah } \\
\text { (tahun) }\end{array}$ & 50 & 60 & 20 & 9 & 15 & 5 & 7 & 6 \\
\hline
\end{tabular}


GEOGRAFIA Online ${ }^{\mathrm{TM}}$ Malaysian Journal of Society and Space 16 issue 3 (247-262)

(C) 2020, e-ISSN 2682-7727 https://doi.org/10.17576/geo-2020-1603-18

\section{Pengurusan Sawah}

Jadual 3 menunjukkan komponen pengurusan sawah dalam kalangan pesawah padi. Sistem kebolehkesanan (traceability system) terbahagi kepada dua kategori iaitu tracing dan tracking. Sistem kebolehkesanan tracing ini membolehkan pengesanan sumber dan sifat pencemaran. Manakala, sistem kebolehkesanan tracking membolehkan tindak balas yang cepat dan tepat dilakukan untuk mengekalkan atau menarik balik produk yang tercemar. Kedua-dua sistem keberkesanan tersebut dapat mengelakkan penggunaan produk tercemar dan mengurangkan kerosakan hasil pertanian. Hasil kajian ini mendapati bahawa penggunaan teknologi untuk tracing dan tracking oleh pesawah di Sekinchan dan pihak Jabatan Pertanian adalah masih rendah bagi mengesan pencemaran yang berlaku semasa proses penanaman atau lepas tuaian padi.

Jadual 3. Aspek pengurusan sawah dalam kalangan pesawah padi

\begin{tabular}{|c|c|c|c|c|c|c|c|c|}
\hline \multirow{2}{*}{$\begin{array}{l}\text { Elemen GAP dalam Aspek } \\
\text { Pengurusan Sawah }\end{array}$} & \multicolumn{4}{|c|}{ Pesawah Ada Sijil MyGAP } & \multicolumn{4}{|c|}{ Pesawah Tiada Sijil MyGAP } \\
\hline & PP1 & PP2 & PP3 & PP4 & PP5 & PP6 & PP7 & PP8 \\
\hline \multicolumn{9}{|l|}{ Sistem kebolehkesanan } \\
\hline Tracing & $\mathrm{O}$ & $\mathrm{O}$ & $\mathrm{O}$ & $\mathrm{O}$ & $\mathrm{O}$ & $\mathrm{O}$ & $\mathrm{O}$ & $\mathrm{O}$ \\
\hline Tracking & $\mathrm{O}$ & $\mathrm{O}$ & $\mathrm{O}$ & $\mathrm{O}$ & $\mathrm{O}$ & $\mathrm{O}$ & $\mathrm{O}$ & $\mathrm{O}$ \\
\hline Rekod ladang & $\mathrm{XX}$ & $\mathrm{XX}$ & $\mathrm{XX}$ & $\mathrm{XX}$ & $\mathrm{X}$ & $\mathrm{X}$ & $\mathrm{X}$ & $\mathrm{X}$ \\
\hline \multicolumn{9}{|l|}{$\begin{array}{l}\text { Sejarah dan pengurusan } \\
\text { tapak }\end{array}$} \\
\hline Sejarah tapak & $\mathrm{O}$ & $\mathrm{O}$ & $\mathrm{O}$ & $\mathrm{O}$ & $\mathrm{O}$ & $\mathrm{O}$ & $\mathrm{O}$ & $\mathrm{O}$ \\
\hline Pengurusan tapak & $X$ & $X$ & $X$ & $\mathrm{X}$ & $X$ & $\mathrm{X}$ & $X$ & $\mathrm{X}$ \\
\hline
\end{tabular}

Pesawah juga tidak mengambil berat terhadap hasil pengeluaran mereka sama ada ia tercemar atau tidak kerana menyerahkan peranan tersebut kepada pihak jentuai swasta dan pengilang untuk menentukan kedudukan produk mereka di pasaran. Sebaliknya, kajian De Baerdemaeker (2013) membuktikan kesan penggunaan teknologi (seperti automasi dan robotik) berupaya untuk mengesan punca pencemaran serta mampu merawat hasil pertanian. Penggunaan teknologi ini juga mampu menghasilkan data yang boleh digunakan untuk mengesan punca awal pencemaran produk pertanian dengan memenuhi kriteria GAP. Secara ringkasnya, elemen sistem kebolehkesanan ini merupakan item yang penting dan perlu memberi penekanan utama dalam pelan tindakan pertanian padi untuk mematuhi keperluan standard MS 1784:2005 (DOA, 2016). Namun dalam kajian ini mendapati elemen kebolehkesanan tidak dilaksanakan oleh pesawah di Sekinchan.

Elemen rekod ladang yang diaplikasi oleh pesawah yang mempunyai sijil MyGAP lebih teratur dan sistematik berbanding pesawah yang tidak mempunyai sijil MyGAP. Hasil kajian menunjukkan semua informan mempunyai rekod ladang masing-masing mengenai pembelian baja dan racun kimia, serta tarikh pembajaan dan penyemburan racun. Walau bagaimanapun, rekod ladang bagi informan yang mempunyai pensijilan MyGAP adalah lebih sistematik kerana menggunakan buku rekod ladang yang dibekalkan oleh Jabatan Pertanian. Manakala, pesawah yang tidak mempunyai MyGAP lebih ringkas dan hanya ditulis dalam buku nota poket atau ditandakan pada kalendar sahaja.

Manakala, elemen tapak terbahagi kepada dua kategori iaitu sejarah tapak dan pengurusan tapak. Semua informan melaksanakan pengurusan tapak tanpa teratur dan sistematik. 
Elemen sejarah tapak merujuk kepada sejarah penggunaan tapak sawah seperti jenis tanaman yang ditanam sebelum ini dan penilaian risiko tapak tersebut. Kajian ini mendapati semua pesawah tidak melaksanakan elemen tapak sebelum melakukan aktiviti pertanian. Penilaian risiko tapak yang kurang dititikberatkan oleh pesawah dan ia boleh mengundang pelbagai risiko seperti kawasan tanah yang terdedah dengan banjir, masalah tanah yang kurang sesuai untuk pertanian atau masalah pengairan. Kenyataan ini disokong oleh DOA (2016), sejarah dan pengurusan tapak ladang merupakan langkah paling awal dalam pelaksanaan GAP bagi mengelakkan pelbagai risiko dalam proses penanaman padi.

\section{Keselamatan dan kualiti makanan}

Elemen keselamatan dan kualiti makanan merujuk kepada kawalan-kawalan yang dijalankan pada peringkat pengeluaran bagi mengurangkan kontaminasi terhadap pengeluaran padi supaya menghasilkan beras yang bermutu tinggi dan selamat untuk dimakan. Tambahan pula, pengguna di seluruh dunia kini lebih peka terhadap aspek keselamatan dan kualiti makanan. Walau bagaimanapun, terdapat tiga item yang kurang dilaksanakan oleh pesawah terutama dalam aspek peralatan dan pakaian pelindung diri, alat penyembur dan pelupusan bancuhan racun yang berlebihan (rujuk Jadual 4). Penyelidik mendapati bahawa proses meracun dilakukan oleh pekerja asing dan mereka tidak mengambil berat tentang aspek keselamatan ketika pengendalian racun serangga di sawah.

Jadual 4. Aspek keselamatan dan kualiti makanan dalam kalangan pesawah padi

\begin{tabular}{lcccccccc}
\hline Elemen GAP dalam Aspek & \multicolumn{7}{c}{ Pesawah Ada Sijil MyGAP } & \multicolumn{7}{c}{ Pesawah Tiada Sijil MyGAP } \\
\cline { 2 - 8 } Keselamatan dan Kualiti Makanan & PP1 & PP2 & PP3 & PP4 & PP5 & PP6 & PP7 & PP8 \\
\hline Perlindungan tanaman & & & & & & & & \\
$\quad$ Pilihan jenis kimia & $\mathrm{X}$ & $\mathrm{X}$ & $\mathrm{X}$ & $\mathrm{X}$ & $\mathrm{X}$ & $\mathrm{X}$ & $\mathrm{X}$ & $\mathrm{X}$ \\
Rekod penggunaan & $\mathrm{XX}$ & $\mathrm{XX}$ & $\mathrm{XX}$ & $\mathrm{XX}$ & $\mathrm{X}$ & $\mathrm{X}$ & $\mathrm{X}$ & $\mathrm{X}$ \\
Keselamatan, latihan, arahan & $\mathrm{XX}$ & $\mathrm{XX}$ & $\mathrm{XX}$ & $\mathrm{XX}$ & $\mathrm{XX}$ & $\mathrm{XX}$ & $\mathrm{XX}$ & $\mathrm{XX}$ \\
Peralatan dan pakaian pelindung diri* & $\mathrm{O}$ & $\mathrm{O}$ & $\mathrm{O}$ & $\mathrm{O}$ & $\mathrm{O}$ & $\mathrm{O}$ & $\mathrm{O}$ & $\mathrm{O}$ \\
Alat penyembur* & $\mathrm{O}$ & $\mathrm{O}$ & $\mathrm{O}$ & $\mathrm{O}$ & $\mathrm{O}$ & $\mathrm{O}$ & $\mathrm{O}$ & $\mathrm{O}$ \\
Pelupusan bancuhan racun yang & $\mathrm{O}$ & $\mathrm{O}$ & $\mathrm{O}$ & $\mathrm{O}$ & $\mathrm{O}$ & $\mathrm{O}$ & $\mathrm{O}$ & $\mathrm{O}$ \\
berlebihan* & & & & & & & & \\
Penyimpanan racun makhluk perosak & $\mathrm{XX}$ & $\mathrm{XX}$ & $\mathrm{XX}$ & $\mathrm{XX}$ & $\mathrm{X}$ & $\mathrm{X}$ & $\mathrm{X}$ & $\mathrm{X}$ \\
(RMP) & & & & & & & & \\
Pelupusan bekas RMP kosong & $\mathrm{XX}$ & $\mathrm{XX}$ & $\mathrm{XX}$ & $\mathrm{XX}$ & $\mathrm{XX}$ & $\mathrm{XX}$ & $\mathrm{XX}$ & $\mathrm{XX}$ \\
Pengendalian baja & & & & & & & & \\
Keperluan nutrien & $\mathrm{XX}$ & $\mathrm{XX}$ & $\mathrm{XX}$ & $\mathrm{XX}$ & $\mathrm{XX}$ & $\mathrm{XX}$ & $\mathrm{XX}$ & $\mathrm{XX}$ \\
Penggunaan baja & $\mathrm{XX}$ & $\mathrm{XX}$ & $\mathrm{XX}$ & $\mathrm{XX}$ & $\mathrm{X}$ & $\mathrm{X}$ & $\mathrm{X}$ & $\mathrm{X}$ \\
Rekod penggunaan baja & $\mathrm{XX}$ & $\mathrm{XX}$ & $\mathrm{XX}$ & $\mathrm{XX}$ & $\mathrm{X}$ & $\mathrm{X}$ & $\mathrm{X}$ & $\mathrm{X}$ \\
Peralatan pembajaan & $\mathrm{XX}$ & $\mathrm{XX}$ & $\mathrm{XX}$ & $\mathrm{XX}$ & $\mathrm{XX}$ & $\mathrm{XX}$ & $\mathrm{XX}$ & $\mathrm{XX}$ \\
Penyimpanan baja & $\mathrm{XX}$ & $\mathrm{XX}$ & $\mathrm{XX}$ & $\mathrm{XX}$ & $\mathrm{X}$ & $\mathrm{X}$ & $\mathrm{X}$ & $\mathrm{X}$ \\
Baja organik & $\mathrm{O}$ & $\mathrm{O}$ & $\mathrm{O}$ & $\mathrm{O}$ & $\mathrm{O}$ & $\mathrm{O}$ & $\mathrm{O}$ & $\mathrm{O}$ \\
Pengairan & $\mathrm{XX}$ & $\mathrm{XX}$ & $\mathrm{XX}$ & $\mathrm{XX}$ & $\mathrm{XX}$ & $\mathrm{XX}$ & $\mathrm{XX}$ & $\mathrm{XX}$ \\
Kebersihan jentera, peralatan dan diri & & & & & & & & \\
pengendali & & & & & & & & \\
Kebersihan jentera* & $\mathrm{O}$ & $\mathrm{O}$ & $\mathrm{O}$ & $\mathrm{O}$ & $\mathrm{O}$ & $\mathrm{O}$ & $\mathrm{O}$ & $\mathrm{O}$ \\
Kebersihan peralatan & $\mathrm{X}$ & $\mathrm{X}$ & $\mathrm{X}$ & $\mathrm{X}$ & $\mathrm{X}$ & $\mathrm{X}$ & $\mathrm{X}$ & $\mathrm{X}$ \\
Kebersihan diri pengendali & $\mathrm{X}$ & $\mathrm{X}$ & $\mathrm{X}$ & $\mathrm{X}$ & $\mathrm{X}$ & $\mathrm{X}$ & $\mathrm{X}$ & $\mathrm{X}$ \\
Analisis residu & $\mathrm{XX}$ & $\mathrm{XX}$ & $\mathrm{XX}$ & $\mathrm{XX}$ & $\mathrm{X}$ & $\mathrm{X}$ & $\mathrm{X}$ & $\mathrm{X}$ \\
\hline
\end{tabular}


GEOGRAFIA Online ${ }^{\mathrm{TM}}$ Malaysian Journal of Society and Space 16 issue 3 (247-262)

(C) 2020, e-ISSN 2682-7727 https://doi.org/10.17576/geo-2020-1603-18

$\mathrm{O}=$ Tidak dilaksanakan $\quad \mathrm{X}=$ Dilaksanakan $\quad \mathrm{XX}=$ Dilaksanakan dengan teratur dan sistematik

* Dilaksanakan oleh pihak operator swasta secara kontrak

Di bawah elemen pengendalian baja, baja organik tidak digunakan oleh semua pesawah padi (rujuk Jadual 4). Hal ini kerana mereka lebih memilih racun serangga dan jenis padi yang rintang (terhadap penyakit padi) bagi meningkatkan produktiviti padi. Selain itu, penggunaan baja organik juga sukar diaplikasikan kerana pengairan padi yang disalurkan telah mengandungi kandungan baja dan racun serangga. Sehubungan itu, pesawah tidak menggunakan baja organik kerana mereka berasa ianya tidak sesuai digunakan bagi aktiviti pertanian mereka. Sebaliknya, kajian yang dijalankan oleh Vasile et al., (2015) di Romania memberikan bukti empirikal di mana penggunaan baja organik mampu menghasilkan produktiviti sedikit tinggi (slightly higher) berbanding kaedah penggunaan racun serangga.

\section{Pengurusan alam sekitar}

Elemen pengurusan tanaman terdapat tiga item yang tidak dilaksanakan iaitu penanaman, pengurusan penuaian dan pengurusan lepas tuai kecuali PP6 yang melaksanakan proses penanaman sendiri (Jadual 5). Hal ini kerana pengurusan tanaman tidak dilaksanakan oleh pesawah sendiri tetapi ia hanya dilaksanakan oleh pihak operator swasta secara kontrak. Palizada (2016) juga membuktikan bahawa mengikut standard PhilGAP di Filipina terdedah kepada bahaya alam sekitar akibat kekurangan aplikasi elemen pengurusan tanaman sepanjang peringkat pengeluaran pertanian (seperti pengeluaran, penuaian dan lepas tuai hasil pertanian).

Jadual 5. Aspek pengurusan alam sekitar di kalangan pesawah padi

\begin{tabular}{lcccccccc}
\hline Elemen GAP dalam Aspek & \multicolumn{9}{c}{ Pesawah Ada Sijil MyGAP } & \multicolumn{7}{c}{ Pesawah Tiada Sijil MyGAP } \\
Pengurusan Alam Sekitar & PP1 & PP2 & PP3 & PP4 & PP5 & PP6 & PP7 & PP8 \\
\hline Pengurusan tanaman & & & & & & & & \\
Penyediaan tanah* & $\mathrm{X}$ & $\mathrm{X}$ & $\mathrm{X}$ & $\mathrm{X}$ & $\mathrm{X}$ & $\mathrm{X}$ & $\mathrm{X}$ & $\mathrm{X}$ \\
Penanaman* & $\mathrm{O}$ & $\mathrm{O}$ & $\mathrm{O}$ & $\mathrm{O}$ & $\mathrm{O}$ & $\mathrm{X}$ & $\mathrm{O}$ & $\mathrm{O}$ \\
Pembajaan & $\mathrm{XX}$ & $\mathrm{XX}$ & $\mathrm{XX}$ & $\mathrm{XX}$ & $\mathrm{X}$ & $\mathrm{X}$ & $\mathrm{X}$ & $\mathrm{X}$ \\
Pengurusan air & $\mathrm{XX}$ & $\mathrm{XX}$ & $\mathrm{XX}$ & $\mathrm{XX}$ & $\mathrm{XX}$ & $\mathrm{XX}$ & $\mathrm{XX}$ & $\mathrm{XX}$ \\
Pengurusan perosak & $\mathrm{XX}$ & $\mathrm{XX}$ & $\mathrm{XX}$ & $\mathrm{XX}$ & $\mathrm{X}$ & $\mathrm{X}$ & $\mathrm{X}$ & $\mathrm{X}$ \\
Pengurusan penuaian* & $\mathrm{O}$ & $\mathrm{O}$ & $\mathrm{O}$ & $\mathrm{O}$ & $\mathrm{O}$ & $\mathrm{O}$ & $\mathrm{O}$ & $\mathrm{O}$ \\
Pengurusan lepas tuai* & $\mathrm{O}$ & $\mathrm{O}$ & $\mathrm{O}$ & $\mathrm{O}$ & $\mathrm{O}$ & $\mathrm{O}$ & $\mathrm{O}$ & $\mathrm{O}$ \\
Pengurusan alam sekitar & & & & & & & & \\
$\quad$ & $\mathrm{X}$ & $\mathrm{X}$ & $\mathrm{X}$ & $\mathrm{X}$ & $\mathrm{X}$ & $\mathrm{X}$ & $\mathrm{X}$ & $\mathrm{X}$ \\
Pengurusan tanah & $\mathrm{XX}$ & $\mathrm{XX}$ & $\mathrm{XX}$ & $\mathrm{XX}$ & $\mathrm{XX}$ & $\mathrm{XX}$ & $\mathrm{XX}$ & $\mathrm{XX}$ \\
Pengurusan air & $\mathrm{O}$ & $\mathrm{O}$ & $\mathrm{O}$ & $\mathrm{O}$ & $\mathrm{O}$ & $\mathrm{O}$ & $\mathrm{O}$ & $\mathrm{O}$ \\
Pengurusan udara & $\mathrm{O}$ & $\mathrm{O}$ & $\mathrm{O}$ & $\mathrm{O}$ & $\mathrm{O}$ & $\mathrm{O}$ & $\mathrm{O}$ & $\mathrm{O}$ \\
Pengurusan biodiversiti & $\mathrm{X}$ & $\mathrm{X}$ & $\mathrm{X}$ & $\mathrm{X}$ & $\mathrm{X}$ & $\mathrm{X}$ & $\mathrm{X}$ & $\mathrm{X}$ \\
Pengurusan pencemaran & & & & & & & & \\
sisa ladang & & & & & &
\end{tabular}

$\mathrm{O}=$ Tidak dilaksanakan $\quad \mathrm{X}=$ Dilaksanakan $\quad \mathrm{XX}=$ Dilaksanakan dengan teratur dan sistematik

* Dilaksanakan oleh pihak operator swasta secara kontrak

Bagi mendapatkan sijil GAP, elemen pengurusan alam sekitar amat ditekankan meliputi pengurusan tanah, nutrisi tanaman, pengurusan sisa dan pencemaran, pemuliharaan alam sekitar, pengurusan tenaga dan pengurusan air (Carvalho, 2017). Namun, hasil kajian ini mendapati bahawa aspek pengurusan udara dan bioderversiti tidak diberi penekanan oleh semua pesawah 
padi. Informan bersetuju bahawa mereka membakar saki baki jerami padi di dalam petak sawah selepas proses penuaian padi. Proses pembakaran sisa jerami adalah kaedah yang paling cepat untuk mengosongkan tanah sebagai persediaan bagi menanam padi pada musim akan datang. Pembakaran terbuka mengakibatkan berlakunya pencemaran udara sedangkan sisa jerami mempunyai potensi untuk menghasilkan produk sampingan. Berdasarkan kajian yang dibuat di MADA di Kedah dan Sekinchan, Rosmiza et al., (2014) mengenal pasti bahawa petani hanya mengetahui beberapa kegunaan jerami seperti sumber makanan haiwan, kompos, vermikompos, bekas semaian biji benih dan pembuatan kertas.

\section{Keselamatan, kesihatan dan kebajikan pekerja}

Komponen keselamatan, kesihatan dan kebajikan pekerja juga merupakan salah satu aspek penting yang diberikan penekanan dalam GAP kerana para pekerja mudah terdedah kepada pelbagai risiko sewaktu bekerja (Carvalho, 2017). Sebagai contohnya risiko penggunaan jentera, mesin dan penggunaan bahan kimia yang boleh memberikan kesan terhadap keselamatan dan kesihatan. Keadaan ini dijelaskan oleh kajian Sundar (2006) di mana penggunaan antibodi subterapeutik dalam pengeluaran ternakan; dan kontaminasi air dan hasil pertanian daripada pestisid dan nitrat daripada baja kimia telah mengancam kesihatan pekerja ladang dan pengguna. Berdasarkan Jadual 6 menunjukkan keseluruhan elemen ini tidak dilaksanakan oleh semua pesawah. Hasil kajian ini menunjukkan kebanyakkan pesawah melantik pekerja secara kontrak untuk menjalankan kerja-kerja penyembur racun serangga. Kebanyakkan pesawah tidak menghiraukan komponen keselamatan, kesihatan dan kebajikan terhadap pekerja kontrak tersebut kerana mereka tidak terlibat dalam aktiviti penyembur racun serangga. Situasi ini turut dirasai oleh dapatan kajian Damalas \& Khan, (2016) di Punjab, Pakistan di mana 73\% petani tidak membaca label racun serangga dengan betul sebelum menggunakannya terhadap pertanian kapas mereka. Faktor ini disebabkan oleh kekurangan pendidikan dan pengalaman serta latihan dalam penggunaan racun serangga dengan betul.

Jadual 6. Aspek keselamatan, kesihatan dan kebajikan pekerja dalam kalangan pesawah padi

\begin{tabular}{|c|c|c|c|c|c|c|c|c|}
\hline \multirow{2}{*}{$\begin{array}{l}\text { Elemen GAP dalam Aspek } \\
\text { Keselamatan, Kesihatan dan } \\
\text { Kebajikan Pekerja }\end{array}$} & \multicolumn{4}{|c|}{ Pesawah Ada Sijil MyGAP } & \multicolumn{4}{|c|}{ Pesawah Tiada Sijil MyGAP } \\
\hline & PP1 & PP2 & PP3 & PP4 & PP5 & PP6 & PP7 & PP8 \\
\hline $\begin{array}{l}\text { Keselamatan dan kesihatan } \\
\text { pekerja }\end{array}$ & $\mathrm{O}$ & $\mathrm{O}$ & $\mathrm{O}$ & $\mathrm{O}$ & $\mathrm{O}$ & $\mathrm{O}$ & $\mathrm{O}$ & $\mathrm{O}$ \\
\hline $\begin{array}{l}\text { Pengurusan risiko hazard dan } \\
\text { kemalangan di tempat kerja }\end{array}$ & $\mathrm{O}$ & $\mathrm{O}$ & $\mathrm{O}$ & $\mathrm{O}$ & $\mathrm{O}$ & $\mathrm{O}$ & $\mathrm{O}$ & $\mathrm{O}$ \\
\hline Garis panduan & $\mathrm{O}$ & $\mathrm{O}$ & $\mathrm{O}$ & $\mathrm{O}$ & $\mathrm{O}$ & $\mathrm{O}$ & $\mathrm{O}$ & $\mathrm{O}$ \\
\hline Penggunaan PPE & $\mathrm{O}$ & $\mathrm{O}$ & $\mathrm{O}$ & $\mathrm{O}$ & $\mathrm{O}$ & $\mathrm{O}$ & $\mathrm{O}$ & $\mathrm{O}$ \\
\hline $\begin{array}{l}\text { Persekitaran kerja, peralatan, } \\
\text { jentera }\end{array}$ & $\mathrm{O}$ & $\mathrm{O}$ & $\mathrm{O}$ & $\mathrm{O}$ & $\mathrm{O}$ & $\mathrm{O}$ & $\mathrm{O}$ & $\mathrm{O}$ \\
\hline \multicolumn{9}{|l|}{ Kebajikan pekerja } \\
\hline Tempat tinggal & $\mathrm{O}$ & $\mathrm{O}$ & $\mathrm{O}$ & $\mathrm{O}$ & $\mathrm{O}$ & $\mathrm{O}$ & $\mathrm{O}$ & $\mathrm{O}$ \\
\hline Kesihatan & $\mathrm{O}$ & $\mathrm{O}$ & $\mathrm{O}$ & $\mathrm{O}$ & $\mathrm{O}$ & $\mathrm{O}$ & $\mathrm{O}$ & $\mathrm{O}$ \\
\hline \multicolumn{9}{|l|}{ Latihan } \\
\hline Amalan kultura & $\mathrm{O}$ & $\mathrm{O}$ & $\mathrm{O}$ & $\mathrm{O}$ & $\mathrm{O}$ & $\mathrm{O}$ & $\mathrm{O}$ & $\mathrm{O}$ \\
\hline $\begin{array}{l}\text { Aspek keselamatan dan } \\
\text { kesihatan pekerjaan }\end{array}$ & $\mathrm{O}$ & $\mathrm{O}$ & $\mathrm{O}$ & $\mathrm{O}$ & $\mathrm{O}$ & $\mathrm{O}$ & $\mathrm{O}$ & $\mathrm{O}$ \\
\hline
\end{tabular}


GEOGRAFIA Online ${ }^{\mathrm{TM}}$ Malaysian Journal of Society and Space 16 issue 3 (247-262)

(C) 2020, e-ISSN 2682-7727 https://doi.org/10.17576/geo-2020-1603-18

\begin{tabular}{ccccccccc} 
Berkala dan berterusan & $\mathrm{O}$ & $\mathrm{O}$ & $\mathrm{O}$ & $\mathrm{O}$ & $\mathrm{O}$ & $\mathrm{O}$ & $\mathrm{O}$ & $\mathrm{O}$ \\
\hline $\mathrm{O}=$ Tidak dilaksanakan & $\mathrm{X}$ = Dilaksanakan & $\mathrm{XX}=$ Dilaksanakan dengan teratur dan sistematik
\end{tabular}

\section{Pelaksanaan gap dalam pengurusan tanaman padi dalam kalangan pesawah padi di sekinchan}

Rajah 3 menunjukkan amalan pertanian baik (GAP) dalam pengurusan tanaman padi di kawasan kajian Sekinchan yang perlu dilaksanakan oleh pesawah bagi mendapatkan pensijilan MyGAP. Hasil kajian mendapati amalan pertanian yang dilaksanakan oleh semua pesawah padi di kawasan kajian adalah pada tahap yang sederhana di mana hanya tiga daripada empat komponen GAP telah dilaksanakan seperti pengurusan sawah, keselamatan dan kualiti makanan serta pengurusan persekitaran. Manakala daripada 13 elemen GAP yang ditetapkan hanya sembilan elemen sahaja yang dipraktikkan di kawasan kajian.

Hasil kajian mendapati tiada sistem kebolehkesanan diwujudkan untuk produk beras di kawasan kajian, sama ada bagi padi yang dihasilkan oleh pesawah yang mempunyai sijil MyGAP mahupun pesawah yang tidak mempunyai sijil MyGAP. Sistem kebolehkesanan tersebut penting dalam memastikan hasil pertanian bebas daripada pencemaran dan selamat dimakan. MOA harus menekankan sistem keberkesanan bagi tanaman padi kerana maklumat mengenai sumber beras yang berada di pasaran akan lebih mudah dikenal pasti melalui nombor sijil MyGAP. Nombor sijil MyGAP tersebut membantu juga pengguna untuk mendapatkan maklumat lengkap mengenai kualiti produk beras di sepanjang rantaian pengeluaran. Kajian yang dijalankan oleh Irsyaputra et al., (2018) di Indonesia memberi bukti empirikal bahawa pembangunan sistem berasaskan Quick Response Code (QR Code) berperanan mengesan dan merekodkan setiap peringkat aktiviti pertanian. Penjelasan ini dihuraikan dengan lebih lanjut oleh kajian Ruiz-Garcia et al., (2010) di mana penggunaan web dalam sistem kebolehkesanan berfungsi sebagai pemprosesan data, penyimpanan dan pemindahan data. Sistem web tersebut memudahkan semua pihak dapat mengakses maklumat seperti hasil pemprosesan produk, pembungkusan, penghantaran dan pengedaran. 


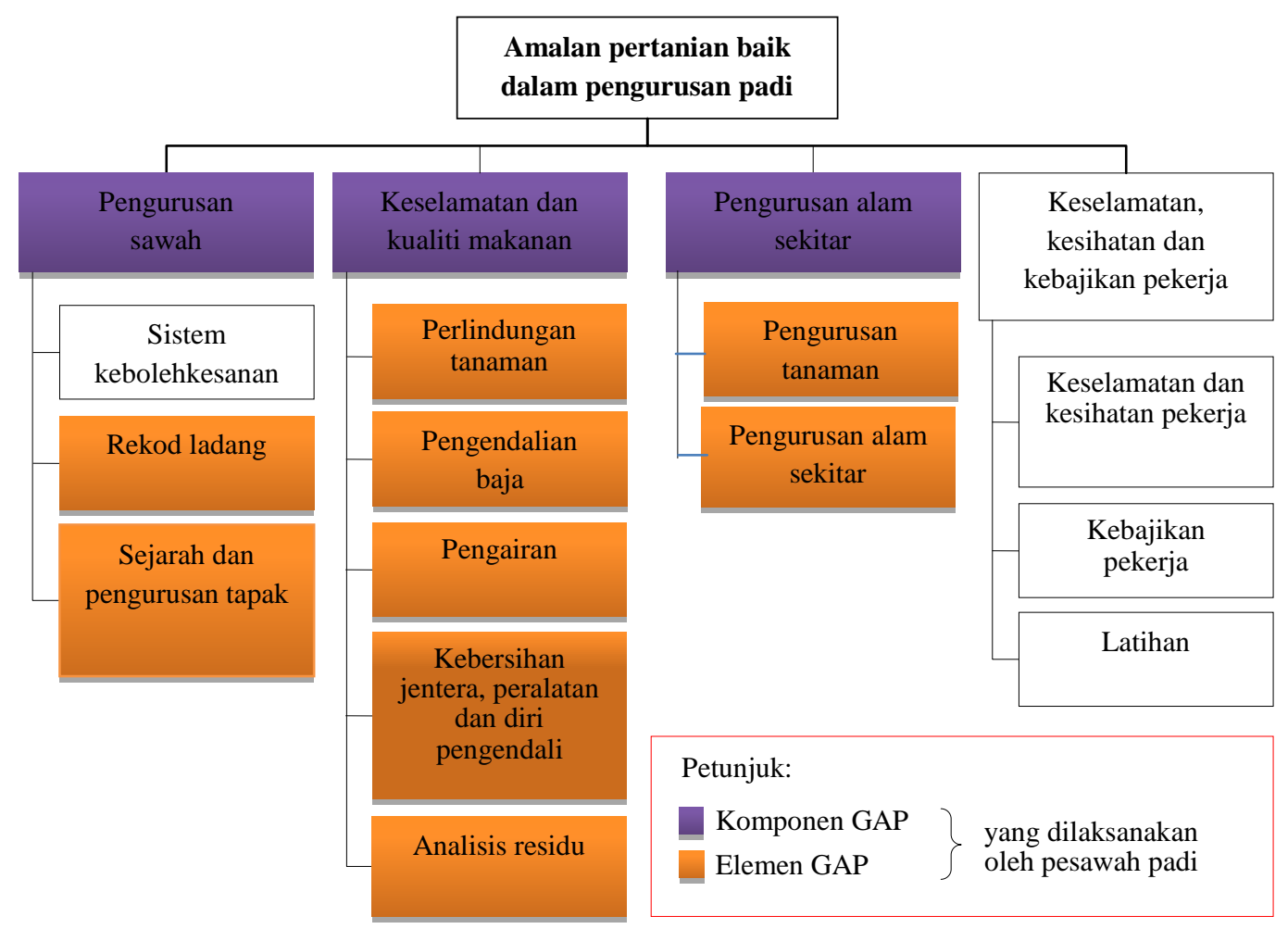

Rajah 3. Amalan pertanian baik dalam pengurusan tanaman padi di kawasan kajian

Komponen keselamatan, kesihatan dan kebajikan pekerja adalah tidak dititikberatkan oleh semua pesawah. Hal ini kerana pekerja kontrak melakukan penyediaan tanah, penanaman, pembajaan dan penggunaan jentera bagi pesawah tersebut. Sebenarnya, tanggungjawab aspek keselamatan, kesihatan dan kebajikan pekerja bukan hanya menjadi tanggungjawab pesawah tetapi ia juga menjadi tanggungjawab pekerja kontrak itu sendiri. Kesedaran kepentingan komponen keselamatan, kesihatan dan kebajikan ini tidak boleh dipandang ringan kerana ia melibatkan nyawa pekerja. Hasil kajian ini mendapati masih ditahap kesedaran yang rendah dalam kalangan pesawah dan pekerja kontrak terhadap komponen tersebut. Pernyataan ini disokong oleh penemuan kajian Oluwole \& Cheke, (2009) di mana sebanyak $94.7 \%$ petani di Ekiti State, Nigeria tidak mendapat latihan dalam cara penyimpanan racun serangga yang betul sehingga mendatangkan risiko terhadap kesihatan seperti masalah mata (91.3\%), masalah kulit (87.3\%), loya (86.0\%), sakit kepala $(83.3 \%)$ dan muntah $(58.0 \%)$. Selain itu, satu lagi kajian dijalankan oleh Plianbangchang et al. (2009) mendapati ramai petani di Thailand menggunakan endosulfan (sejenis pestisid yang berbahaya) yang telah diharamkan oleh kerajaan Thailand sejak 2004. Dapatan kajian tersebut juga mengakui bahawa petani tidak memakai peralatan perlindungan diri (PPE); cara penggunaan dan pembuangan pestisid dengan tidak betul; serta tidak mempunyai stor simpanan sesuai. Keadaan ini jelas menunjukkan keselamatan kesihatan dan kebajikan merupakan salah satu komponen yang penting kerana ia memberi kesan terhadap tahap kesihatan petani dan juga mendatangkan kesan terhadap alam sekitar. 
GEOGRAFIA Online ${ }^{\mathrm{TM}}$ Malaysian Journal of Society and Space 16 issue 3 (247-262)

(C) 2020, e-ISSN 2682-7727 https://doi.org/10.17576/geo-2020-1603-18

\section{Kesimpulan}

Amalan pertanian baik (MyGAP) ini merupakan suatu kaedah penanaman yang perlu dipraktikan oleh semua petani kerana ia bukan sahaja untuk mendapatkan hasil yang berkualiti malahan ia turut menjaga kelestarian alam sekitar. Perubahan citarasa dan kesedaran pengguna yang lebih cenderung kepada pemilihan produk yang memberikan manfaat kesihatan. Sekiranya produk yang mempunyai kualiti yang tinggi, ia mampu memberi nilai tambah dalam aspek kesihatan serta selamat untuk dimakan. Keseluruhan amalan pertanian baik yang dilaksanakan oleh pesawah di Skinchan berada pada tahap yang sederhana dan hanya melepasi kelayakan minimun sahaja bagi mendapatkan pensijilan MyGAP. Walau bagaimanapun, ia merupakan langkah permulaan yang baik bagi petani di Malaysia ke arah pertanian yang lestari tanpa menjejaskan alam sekitar. Di samping itu, dapat membekalkan produk keselamatan makanan yang berkualiti serta terjamin dari segi kesihatan penduduk Malaysia. Kerjasama daripada MOA harus mempergiatkan usaha mempromosikan kesedaran dalam kalangan pesawah mengenai kepentingan pensijilan MyGAP. Penambahbaikkan sistem perkhidmatan dalam MyGAP juga perlu ditingkatkan ke arah yang lebih efisen dan efektif agar semua pesawah padi di Malaysia menggunakan MyGAP secara meluas.

\section{Penghargaan}

Kami mengucapkan terima kasih kepada pihak Jabatan Pertanian Negeri Selangor, Pejabat Pertanian Daerah Sabak Bernam dan Pusat Khidmat Pengembangan Kawasan Sekinchan terutamanya kepada Puan Aini Wiznati binti Lasuan (Pegawai Pertanian Daerah Sabak Bernam) dan Puan Nurul Inani binti Shahadan (Pegawai Pengembangan Pertanian Kawasan Sekinchan) atas kerjasama, perkongsian maklumat dan kebenaran yang diberikan kepada kami untuk menjalankan kajian di kawasan mereka. Terima kasih juga kami ucapkan kepada pesawahpesawah padi di Sekinchan atas kerjasama yang diberikan dalam kajian ini.

\section{Rujukan}

Amekawa, Y. (2009). Reflections on the growing influence of good agricultural practices in the Global South. Journal of Agricultural and Environmental Ethics, 22(6), 531-557. https://doi.org/10.1007/s10806-009-9171-8

Aune, J. B. (2012). Conventional, Organic and Conservation Agriculture: Production and Environmental Impact. In Agroecology and Strategies for Climate Change (pp. 149165). Springer Netherlands.

Avery, A. A. \& Avery D. T. (2008). The local organic food paradigm. Georgetown Journal of International Affairs, 9(1), 33-40.

Baudoin, W., Nono-Womdim, R., Lutaladio, N., Hodder, A., Castilla, N., Leonardi, C., Qaryouti, M. (2013). Good Agricultural Practices for greenhouse vegetable crops. Good Agricultural Practices for greenhouse vegetable crops. https://doi.org/10.1201/b13737-8

Carvalho, F. P. (2017). Pesticides, environment, and food safety. Food and Energy Security. https://doi.org/10.1002/fes3.108

Chan, K. (2016). Manual on Good Agricultural Practices (GAP). Asian Productivity Organization. 
GEOGRAFIA Online ${ }^{\mathrm{TM}}$ Malaysian Journal of Society and Space 16 issue 3 (247-262)

(C) 2020, e-ISSN 2682-7727 https://doi.org/10.17576/geo-2020-1603-18

Cooper, D.R \& Schindler, P. S. (2001). Business Research Method (7th ed.). New York: McGraw-Hill.

Curtis, M. (2012). Asia at the Crossroads: Prioritising conventional farming or sustainable agriculture? t.tp.: ActionAid International

Damalas, C. A., \& Khan, M. (2016). Farmers' attitudes towards pesticide labels: Implications for personal and environmental safety. International Journal of Pest Management, 62(4), 319-325. https://doi.org/10.1080/09670874.2016.1195027

DOA. (2016). Senarai Penerima Sijil Pensijilan MyGAP. Portal Rasmi Jabatan Pertanian. http://www.doa.gov.my/index/resources/perkhidmatan/skim_pensijilan/penerima_sijil_ myGAP_jun2016.pdf [12 Januari 2017].

Doni, F., Isahak, A., Ghazali, R., Mohd Zain, C. R. C., Sulaiman, N., Siwar, C., \& Wan Yusoff, W. M. (2016). Transforming the economy of small scale rice farmers in Malaysia via system of rice intensification (SRI). Ecology, Environment and Conservation, 22(3), $1151-1157$.

EPU. (2015). Eleventh Malaysia plan, 2015-2020. Economic Planning Unit, Prime Minister's Department, Putrajaya, Malaysia. Retrieved from https://www.pmo.gov.my/dokumen attached/speech/files/RMK11_Ucapan.pdf

Feher. I. \& Beke, J. (2013). The rationale of sustainable agricuklture. Iustum Aequum Salutare, 9(3), 73-87.

FOA. (2003). Report of the Expert Consultation on a Good Agricultural Practices (GAP) Approach. FAO Agriculture Department Report. Rome: Food and Agriculture Organization of the United Nations.

Fuad, M. J. M., Junaidi, A. B., Habibah, A., Hamzah, J., Toriman, M. E., Lyndon, N., Azima, A. M. (2012). The Impact of Pesticides on Paddy Farmers And Ecosystem. Advances in Natural and Applied Sciences, 6(1),65-70.

Gomiero, T. (2018). Food quality assessment in organic vs. conventional agricultural produce: Findings and issues. Applied Soil Ecology, 123(June), 714-728. https://doi.org/10.1016/ j.apsoil.2017.10.014

IADA Barat Laut Selangor. (n.d.). Warga Tani: Portal Rasmi IADA Barat Laut Selangor. http://www.iadabls.gov.my/?q=laman/profil-petani [20 November 2015].

Ili Akmal Mohd Razif. (2015). Sayameana: Kampung Sekinchan. 10 April. http://sayameana.blogspot.my/2015/04/kampung-sekinchan.html [24 Oktober 2016].

Irsyaputra, K., Seminar, K., \& Yuliati, L. N. (2018). The development of a traceability system on organic rice production chain, 3(07), 7-14.

Jabatan Standard Malaysia. (2016). Good Agricultural Practice (GAP) - Crop commodities (Second revision) (MS 1784:2016). Putrajaya.

Josse De Baerdemaeker. (2013). Precision agriculture technology and robotics for good agricultural practices. IFAC Proceedings Volumes (IFAC-PapersOnline), 1(PART 1), 14. https://doi.org/10.3182/20130327-3-JP-3017.00003

Kaewboonchoo, O., Kongtip, P., \& Woskie, S. (2015).Occupational health and safety for agricultural workers in Thailand: Gaps and recommendations, with a focus on pesticide use. New Solutions, 25(1), 102-120. https://doi.org/10.1177/1048291115569028

Mishra, B., Gyawali, B. R., Paudel, K. P., Poudyal, N. C., Simon, M. F., Dasgupta, S., \& Antonious, G. (2018). Adoption of sustainable agriculture practices among farmers in Kentucky, USA. Environmental Management, (Zaharia 2010). https://doi.org/10.1007/s00267-018-1109-3

MOA. (n.d.). MyGAP: Portal Rasmi Kementerian Pertanian dan Industri Asas Tani Malaysia. 
GEOGRAFIA Online ${ }^{\mathrm{TM}}$ Malaysian Journal of Society and Space 16 issue 3 (247-262)

(C) 2020, e-ISSN 2682-7727 https://doi.org/10.17576/geo-2020-1603-18

Diakses November 20, 2015. http://www.moa.gov.my/mygap.

MOA. (2013). Garis Panduan MyGAP. Putrajaya: Kementerian Pertanian dan Industri Asas Tani Malaysia.

Mohd Hafizi, I. (2014). The past, present and future of Sekinchan, Selangor by looking into its SWOT. In Sekinchan Insight (pp. 24-42). Behrang Ulu: Institut Tanah dan Ukur Negara.

Oluwole, O., \& Cheke, R. A. (2009). Health and environmental impacts of pesticide use practices: A case study of farmers in Ekiti State, Nigeria. International Journal of Agricultural Sustainability, 7(3), 153-163. https://doi.org/10.3763/ijas.2009.0431

Palizada, S. A. (2016). Overview of the Philippine good agricultural practices (PhilGAP) certification program. Manila: Crop Research and Production Support Division, Bureau of Plant Industry of The Philippines.

Plianbangchang, P., Jetiyanon, K., \& Wittaya-areekul, S. (2009). Pesticide use patterns among small-scale farmers: A case study from phitsanulok, Thailand. Southeast Asian Journal of Tropical Medicine and Public Health, 40(2), 401-410.

Rosmiza, M. Z., Davies, W. P., Aznie, C. R. R., Mazdi, M., \& Jabil, M. J. (2014). Farmers' knowledge on potential uses of rice straw: an assessment in MADA and Sekinchan, Malaysia. Geografia-Malaysian Journal of Society and Space, 10(5), 30-43. https://doi.org/10.1109/TMAG.2016.2607518

Ruiz-Garcia, L., Steinberger, G., \& Rothmund, M. (2010). A model and prototype implementation for tracking and tracing agricultural batch products along the food chain. Food Control, 21(2), 112-121. https://doi.org/10.1016/j.foodcont.2008.12.003

Srisopaporn, S., Jourdain, D., Perret, S. R., \& Shivakoti, G. (2015). Adoption and continued participation in a public Good Agricultural Practices program: The case of rice farmers in the Central Plains of Thailand. Technological Forecasting and Social Change, 96, 242-253. https://doi.org/10.1016/j.techfore.2015.03.016

Sundar. (2006). Environment \& sustainable development. In Policy Issues in Sustainable Development. (p. 178). New Delhi: APH Publishing Corporation.

Tal, A. (2018). Making conventional agriculture environmentally friendly: Moving beyond the glorification of organic agriculture and the demonization of conventional agriculture. Sustainability (Switzerland), 10(4). https://doi.org/10.3390/su10041078

Tsutsui, M. H., Kobayashi, K., \& Miyashita, T. (2018). Temporal trends in arthropod abundances after the transition to organic farming in paddy fields. PLoS ONE, 13(1), 114. https://doi.org/10.1371/journal.pone.0190946

United Nations Conference on Environment \& Development. (1992). United Nations Conference on Environment \& Development Rio de Janerio , Brazil. In Reproduction. United Nations Sustainable Development. https://doi.org/10.1007/s11671-008-9208-3

Vasile, A. J., Popescu, C., Ion, R. A., \& Dobre, I. (2015). From conventional to organic in Romanian agriculture - Impact assessment of a land use changing paradigm. Land Use Policy, 46, 258-266. https://doi.org/10.1016/j.landusepol.2015.02.012

Wennberg, A. (2014). Food and Agriculture Organization of the United Nations. In Encyclopedia of Toxicology: Third Edition. https://doi.org/10.1016/B978-0-12-3864543.00988-X 